\title{
Effect of Soil Amendments on Soil Fertility and Maize Productivity in A Newly Reclaimed Soil
}

\author{
Seham M. Abdel-Azeem
}

\begin{abstract}
Two field experiments were carried out at private farm at El-quntra Shark, Ismailia Governorate, Egypt, during two successive seasons of summer 2018 and 2019 to study the effect of soil amendments (biochar, compost and biofertilizer) with or without different rates of nitrogen mineral fertilizer on the fertility of study soil and maize productivity. In both seasons, each experiment was carried out in split plot design with three replicates. The obtained results indicated that the soil $\mathrm{pH}$ and $\mathrm{EC}\left(\mathrm{dSm}^{-1}\right)$ tended to decrease with increasing nitrogen mineral combined with compost and bio-fertilizer than biochar. The high of mean values of available $N, P$ and $K$ in soil was $44.04,5.93$ and $177.00 \mathrm{mg} / \mathrm{kg}$ soil for soil treated by compost together with nitrogen mineral fertilizer. Application of soil amendments had positive significant effect for $\mathrm{Fe}$ and $\mathrm{Zn}$, while was not significant for Mn content in soil. The effect of biochar, compost and bio-fertilizer combined with different rates of nitrogen mineral fertilizer on plant height $(\mathrm{cm})$, weight of 100 grains (g), weight of stover (ton/fed), weight of ears (ton/fed) and weight of grains yield (ton/fed) were increased with increasing nitrogen mineral application rate except plants treated with bio-fertilizer. The effect of soil amendments application significantly increased $\mathbf{N}, \mathbf{P}$ and $K$ concentrations in stover and grains. The interaction between soil amendments and different rates of nitrogen mineral fertilizer showed insignificant affect on the amount of $\mathrm{Fe}, \mathrm{Mn}$ and $\mathrm{Zn}$ in stover and grains of maize. The application of soil amendments improved the growth characters and grain yield of maize and also the chemical and physical properties of soil.
\end{abstract}

Key world: Soil amendments, biofertilizer, Soil fertility, Maize productivity.

\section{INTRODUCTION}

Most of Egyptian soils are sandy soils and faces large constraints due to low water holding and nutrient retention capacity, and accelerated mineralization of soil organic matter, (Abdelraouf et al., 2017). Egypt occupies a total area of about 100 million hectares, out of this area, is about 3.1 million hectares as cultivated area. The newly reclaimed lands ( 0.8 million hectares) included sandy and calcareous soils, which the soil in poor in organic matter and macro-and micronutrients) (Abd El-Hadi, 2004). Sandy soil properties such as soil organic carbon (SOC), N, P, and K were significantly increased whereas soil $\mathrm{pH}$ was decreased by the combination with compost and fertilizers applications (Muhammad et al ., 2017).
Biochar (BC) is a carbonaceous residue produced through the thermal breakdown of organic materials under limited conditions of oxygen. Biochar was characterized by hydrophobic groups such cyclic acid anhydrides ( $\mathrm{C}-\mathrm{C}$ and $\mathrm{C}-\mathrm{O}$ ); asymmetric carboxylates $\left(\mathrm{CO}_{2}\right)$, aromatic ketones $(\mathrm{C}=\mathrm{O})$; silicon $(\mathrm{Si}-\mathrm{O})$; and hydrophilic groups such carbonates $(\mathrm{C}-\mathrm{O})$ and silanol (Si-O-H). With these classifications, this biochar was determined to have a high hydrophobicity (Duarte et al., 2019). Leonard, (2013) suggested that the biochar is used as a soil amendment for improving soil quality and enhancing carbon sequestration. Biochar is positive improvement of soil physical and hydraulic properties. Tomasz et al (2016) indicated that biochar application significantly affected the physical properties of the sandy soil. Biochar application showed lower soil bulk density values. Khaled and Jeff, (2019) reported that the application of biochar led to a decrease in soil $\mathrm{pH}$ and increase in soil OM and CEC. Application rates of biochar can significantly improve soil physical quality in terms of bulk density (BD), and water holding capacity (WHC). However, little data are available on surface area (SA), aggregation stability, and penetration resistance (PR), Atanu and Rattan, (2013). Biochar is abundant in the organic matter, water holding capacity, nutrient-retaining capacity, and bioavailable nutrition elements (e.g., N, P, K, Ca), Lehmann and Josehp, (2009). The biochar amendment enhanced the formation and stabilization of the soil macro-aggregates, especially in the sandy loam soil. Aggregate formation and stabilization are affected by the type and amount of organic materials, which include the microorganisms and microbial synthesis (Ouyang et al., 2013). Biochar produced at 300 or $400 \mathrm{C}^{\circ}$ and added with NPK provided the highest yield compared to that with the NPK alone treatment and also compared to the biochar produced at 500 or $600 \mathrm{C}^{\circ}$ treatments (Khaled and Jeff, 2019).

Bio-fertilizer plays a substantial role in chemical and biological transformations in soil and maintains soil fertility. The major biological elements, (carbon, nitrogen, oxygen and sulphur) are subjected to comparable cyclic processes. Nevertheless, on top of them is the nitrogen cycle, from both ecological and economic viewpoints (Idriss 2004). Bio-fertilizers used can either fix atmospheric nitrogen and solublize phosphate or stimulate plant growth through synthesis

DOI: $10.21608 / A S E J A I Q J S A E .2020 .81529$

${ }^{1}$ Soils, Water and Environment Research Institute. (SWERI), ARC, Giza, Egypt.

Received February26, 2020, Accepted March25, 2020 
of growth promoting substances led to enhancing the decomposition of plant residues to release vital nutrients (Wu et al., 2006). Biofertilizer application led to improved soil chemical and biological characteristics; moreover due to the use of low doses of chemical fertilizers, agricultural production will be free from contaminants (Salimpour et al., 2010). Rhizobacteria improve plant growth employing a variety of growth promoting mechanisms including nutrient uptake, root growth, proliferation, biocontrol activities, producing, phosphate solubilizing bacterial strain. Also, that in fully fertilized control plants, biomass was high and grain yield was low while addition of halotolerant PGPR with half fertilization exhibited higher grain yield as compared to biomass. (Rajput et al,. 2013).

Compost can improve the soil capacity to produce safe clean products and importantly increase the potential for large scale organic food production (Paulin and Peter, 2008). Claudio et al., (2007) found that the soil $\mathrm{pH}$ increment depends on the soil and the compost characteristics as well as on the dose and time of application. Increasing the period between compost application and the plantation to 30 days resulted in low soil $\mathrm{pH}$ values Claudio et al., (2007).

Maize is cultivated in all agro-climatic zones in Egypt from north to south. The cultivated area of maize, in 2013, was 703,921 hectare with average productivity of 7.72 ton/ha, Ouda and Noreldin (2016). In Egypt, the total production of maize was 7.10 million ton in 2017 produced from an area of 2.192 million fed, with an average yield of $3239.19 \mathrm{~kg} / \mathrm{fed}$ El-Hosary et al (2019).

The objective of this study therefore, was to determine the suitable combination of $\mathrm{N}$ mineral fertilizer, biofertilizers (PGPR), compost and biochar to obtain high crop yield with good quality of maize and soil fertility. In addition, the possibility of reducing the inputs of chemical fertilizers was studied to produce crop of maize under sandy soil conditions.

Table 1. Some physical and chemical properties of the used field experimental soil Particle size distribution (\%)

\begin{tabular}{|c|c|c|c|c|c|c|c|}
\hline \multicolumn{5}{|c|}{ Particle size distribution (\%) } & \multirow[b]{2}{*}{ Texture } & \multirow[b]{2}{*}{ O.M (\%) } & \multirow{2}{*}{$\begin{array}{c}\mathrm{CaCO}_{3} \\
(\%)\end{array}$} \\
\hline $\begin{array}{c}\text { Coarse } \\
\text { sand }\end{array}$ & Fine sand & Silt & Clay & & & & \\
\hline 14.70 & 65.35 & 7.15 & 12.80 & & Sandy & 0.55 & 1.25 \\
\hline \multirow{2}{*}{$\mathrm{pH}(1: 2.5)$} & $\mathrm{EC}$ & \multicolumn{4}{|c|}{ Cations (meq/l) } & \multicolumn{2}{|c|}{ Anions (meq/l) } \\
\hline & $\left(\mathrm{dSm}^{-1}\right)$ & $\mathrm{Ca}^{++}$ & $\mathrm{Mg}^{++}$ & $\mathrm{Na}^{+}$ & $\mathrm{K}^{+}$ & $\mathrm{HCO}_{3}{ }^{-}$ & $\mathrm{SO}_{4}^{--}$ \\
\hline 7.94 & 1.39 & 4.58 & 2.93 & 5.54 & 0.85 & 1.18 & 6.89 \\
\hline \multicolumn{4}{|c|}{ Available macronutrients $\left(\mathrm{mg} \mathrm{kg}^{-1}\right)$} & \multicolumn{4}{|c|}{ Available micronutrients $\left(\mathrm{mgkg}^{-1}\right)$} \\
\hline $\mathrm{N}$ & $\mathrm{P}$ & K & & $\mathrm{Fe}$ & & $\mathrm{Mn}$ & $\mathrm{Zn}$ \\
\hline 32.15 & 5.17 & 160.10 & & 2.85 & & 1.47 & 0.59 \\
\hline
\end{tabular}


Table 2. Chemical analysis of compost

\begin{tabular}{|c|c|c|c|c|c|c|c|c|c|c|c|}
\hline \multirow{2}{*}{$\begin{array}{c}\text { Moisture } \\
\text { content \% }\end{array}$} & \multirow{2}{*}{$\begin{array}{c}\mathrm{EC} \mathrm{dSm}^{-1} \\
(\text { extract } \\
\text { compost and } \\
\text { water1:5) }\end{array}$} & \multirow{2}{*}{$\underset{(1: 2.5)}{\text { pH }}$} & O.C & $\begin{array}{l}\mathrm{C} / \mathrm{N} \\
\text { ratio }\end{array}$ & O.M & $\mathbf{N}$ & $\mathbf{P}$ & $\mathbf{K}$ & $\mathbf{F e}$ & Mn & Zn \\
\hline & & & \multicolumn{6}{|c|}{$(\%)$} & \multicolumn{3}{|c|}{$\left(\mathrm{mgkg}^{-1}\right)$} \\
\hline $22-27$ & 3.20 & 7.50 & 31.00 & 13.30 & 35 & 2.33 & 0.89 & 4.37 & 312.00 & 112.00 & 98.00 \\
\hline
\end{tabular}

Table 3. Chemical analysis of biochar

\begin{tabular}{|c|c|c|c|c|c|c|c|c|c|c|c|}
\hline \multirow{2}{*}{$\begin{array}{c}\text { Moisture } \\
\text { content \% }\end{array}$} & $\begin{array}{c}\mathrm{EC} \mathrm{dSm}^{-1} \\
\text { (extract }\end{array}$ & pH & $\mathbf{C}$ & $\begin{array}{l}\mathrm{C} / \mathrm{N} \\
\text { ratio }\end{array}$ & O.M & $\mathbf{N}$ & $\mathbf{P}$ & $\mathbf{K}$ & $\mathbf{F e}$ & Mn & $\mathbf{Z n}$ \\
\hline & $\begin{array}{c}\text { biochar and } \\
\text { water1:5) }\end{array}$ & $(1: 2.5)$ & \multicolumn{6}{|c|}{$(\%)$} & \multicolumn{3}{|c|}{$\left(\mathrm{mgkg}^{-1}\right)$} \\
\hline 30 & 4.20 & 8.90 & 30.23 & 20.85 & 44.00 & 1.45 & 0.86 & 7.90 & 332.00 & 110.00 & 78.00 \\
\hline
\end{tabular}

Bio-fertilizer was Azospirillum brasilense (PGPR) applied as coating for grains using the gum media, in the same day of sowing. Bio-fertilizer was applied to soil using a liquid bacteria strain, three times after 30 , 45 and 65 days from planting. The bio-fertilizer was obtained from the Department Microbiology in Soil, Water and Environment Research Inst. Agric. Res. Center, Giza, Egypt. Super phosphate $\left(15.5 \% \mathrm{P}_{2} \mathrm{O}_{5} \%\right)$ fertilizer was applied a rate of $200 \mathrm{~kg} / \mathrm{fed}$ during soil preparation.

Maize seeds (Zea mays $L$ ) cultivar Triple hybrid 310 supplied by Maize Department Filed Crops Res. Inst. ARC, Giza Egypt, were sown on the $12^{\text {th }}$ of May 2018, and 2019. Sowing grain maize was cultivated at $20 \mathrm{~cm}$ distance between plants at the rate of 2- 3 seeds/hill. The seedlings were thinned to one plant /hill at 3-4 leaf stage.

Urea $(46 \% \mathrm{~N})$ was applied as $\mathrm{N}$ fertilizer at from rates $(0,50,75$ and $100 \mathrm{~kg} \mathrm{~N} /$ fed) on three equal doses after 21, 42 and 75 days from seed sowing. Potassium sulphate $\left(48 \% \mathrm{~K}_{2} \mathrm{O}\right)$ was applied at a rate of $75 \mathrm{~kg} / \mathrm{fed}$ at two equal doses after 21 and 45 days from planting.

The maize plants were harvested at full maturity; ten plants were randomly taken from each plot to record the average of the following traits: plant height $(\mathrm{cm})$; weight of 100 grains $(\mathrm{g})$; weight of stover (ton/fed); weight of Ear (ton/fed) and weight of grains yield (ton/fed).

\section{Plant analysis}

Half gram of each oven dried ground maize plants (grains and stover) was digested in $4 \mathrm{ml}$ of $\mathrm{H}_{2} \mathrm{SO}_{4}$ mixed with $2 \mathrm{ml} \mathrm{HCLO}_{4}$ according to the method described by Chapman and Pratt (1961). The plant content of $\mathrm{N}, \mathrm{P}, \mathrm{K}, \mathrm{Fe}, \mathrm{Mn}$ and $\mathrm{Zn}$ was determined in plant digestion using the methods described by Cottenie et al (1982) and Page et al (1982).

The collected data were subjected to statistical analysis using analysis of variance and LSD at 5\% level with MSTAT computer program according to, Gomez and Gomez (1984).

\section{RESULTS AND DISCUSSION}

\section{Effect of soil amendments on some soil properties.}

Soil pH

Data in Table (4) showed that the initial of soil $\mathrm{pH}$, in general, exhibited the high $\mathrm{pH}$ values in the soil studied. Also it is found that the soil $\mathrm{pH}$ tends to decrease slightly and moderate after the applied of compost and biofertilizer more than biochar with or without different nitrogen mineral different rates. The soils of all experimental plot units are characterized by slightly to moderately alkaline conditions, where the $\mathrm{pH}$ value is always around $7.96-7.80$. The soil $\mathrm{pH}$ tends to decrease with increasing nitrogen mineral combined with compost and biofertilizer than biochar. This effect is due to the soil amendments led to reduction in soil $\mathrm{pH}$. These results are in agreement by Simon et al., (2019) found that the biochar combined with nitrogen mineral rates was slightly reduced the $\mathrm{pH}$ by 0.22 than biochar alone. Nasef et al., (2009) indicated that the applied of bio-fertilizer and compost combined with nitrogen mineral fertilizer resulted in reduction of soil $\mathrm{pH}$, due to various acids ( amino acids such as glycine and cysteine as well as humic acid ) or acid forming compounds and active microorganisms. Addition of biochar to soil led to decrease of soil pH (Jha et al., 2010). Albert and Kwame (2018) suggested that the soil $\mathrm{pH}$ in all the biochar- and/or compost-amended soils was above the threshold level $\mathrm{pH}$ below. Reduction in soil $\mathrm{pH}$ may be related to the residual organic matter after different biochemical and chemical changes. In addition, the activity of micro-organisms led to the production of organic acid that was released from the bio-fertilizers (Mohamed et al., 2019).

\section{Soil EC}

Data in Table (4) revealed that the EC value was decreased in all the studied soil treatments after harvest. 
The EC values in the studied soils tend to decrease by increasing nitrogen mineral combined with compost and bio-fertilizer compared with biochar alone or combined with nitrogen mineral fertilizer. The application of soil amendments and the different rates of nitrogen fertilizer to soil significantly decreased soil EC. Also, the interaction between the soil amendments and different rates of nitrogen fertilizer significantly decreased with increasing nitrogen mineral fertilizer. As well as the application of biochar alone was increase of soil salinity, while biochar combined with nitrogen mineral was decrease of soil EC. The relative decreases of mean values soil EC was $5.93 \%$ for soil treated with nitrogen mineral compared without nitrogen. The relative decreases of mean value soil EC were obtained by biochar combined with nitrogen mineral fertilizer 8.22 $\%$ compared with biochar alone. On the other hand, the relative decreases of mean values of EC were $6.92 \%$ for soil treated with compost combined with different rates of nitrogen mineral compared with soil treated with compost alone. The relative decreases of mean value of EC were $6.11 \%$ for soil treated with biofertilizer together by nitrogen mineral rates than soil treated with bio-fertilizer alone.

These results indicated the efficiency use of soil amendments combined with nitrogen mineral fertilizer on decreasing of soil salinity could be arranged as shown in the following order : biochar > compost > bio-fertilizer $>$ nitrogen mineral respectively, compared with used soil amendments alone. These results are in agreement by Jones et al., (2011) who reported that the applying of biochar together $\mathrm{N}$ fertilizer led to decrease of soil salinity (EC). These results may be due to that biochar application has reduced soil bulk density and improved soil aggregate structure, which led to increase total porosity in soil and increase in macropores and in turn to increased water content at low suction pressures led to movement of leaching water that enhance progressive removal for Na-salts (Lei \& Zhang, 2013).

Table 4. Soil pH, EC and macro-micronutrients in soil

\begin{tabular}{|c|c|c|c|c|c|c|c|c|c|}
\hline \multirow[t]{2}{*}{ Soil amendments } & \multirow{2}{*}{$\begin{array}{c}\text { Rates of N } \\
\text { (kg/fed) }\end{array}$} & \multirow[t]{2}{*}{ pH (1:2.5) } & \multirow[t]{2}{*}{$\mathrm{EC}\left(\mathrm{dSm}^{-1}\right)$} & \multicolumn{3}{|c|}{$\begin{array}{c}\text { Available } \\
\text { macronutrients }(\mathrm{mg} / \mathrm{kg}) \\
\end{array}$} & \multicolumn{3}{|c|}{$\begin{array}{c}\text { Available micronutrients } \\
(\mathrm{mg} / \mathrm{kg})\end{array}$} \\
\hline & & & & $\mathbf{N}$ & $\mathbf{P}$ & K & $\mathrm{Fe}$ & Mn & Zn \\
\hline \multirow{4}{*}{ Control } & 0 & 7.92 & 1.35 & 34.20 & 5.23 & 165.00 & 2.88 & 2.49 & 0.61 \\
\hline & 50 & 7.90 & 1.30 & 36.25 & 5.33 & 168.00 & 2.91 & 2.56 & 0.62 \\
\hline & 75 & 7.89 & 1.23 & 41.02 & 5.36 & 172.00 & 2.95 & 2.71 & 0.64 \\
\hline & 100 & 7.88 & 1.18 & 42.17 & 5.41 & 174.00 & 2.99 & 2.85 & 0.66 \\
\hline Mean & & & 1.27 & 38.41 & 5.33 & 169.75 & 2.93 & 2.65 & 0.63 \\
\hline \multirow{4}{*}{ Biochar } & 0 & 7.96 & 1.46 & 37.12 & 5.25 & 167.00 & 2.90 & 2.53 & 0.65 \\
\hline & 50 & 7.92 & 1.35 & 40.15 & 5.75 & 172.00 & 3.02 & 2.66 & 0.74 \\
\hline & 75 & 7.90 & 1.30 & 44.31 & 5.86 & 174.00 & 3.15 & 2.75 & 0.76 \\
\hline & 100 & 7.88 & 1.25 & 45.10 & 6.03 & 180.00 & 3.22 & 2.89 & 0.78 \\
\hline Mean & & & 1.34 & 41.67 & 5.72 & 173.25 & 3.07 & 2.71 & 0.73 \\
\hline \multirow{4}{*}{ Compost } & 0 & 7.90 & 1.30 & 39.42 & 5.38 & 169.00 & 2.92 & 2.51 & 0.68 \\
\hline & 50 & 7.88 & 1.24 & 42.10 & 5.93 & 174.00 & 3.08 & 2.64 & 0.75 \\
\hline & 75 & 7.86 & 1.17 & 46.25 & 6.12 & 180.00 & 3.15 & 2.73 & 0.79 \\
\hline & 100 & 7.80 & 1.12 & 48.37 & 6.27 & 185.00 & 3.25 & 2.95 & 0.84 \\
\hline Mean & & & 1.21 & 44.04 & 5.93 & 177.00 & 3.10 & 2.71 & 0.77 \\
\hline \multirow{4}{*}{ Biofertilizer } & 0 & 7.91 & 1.31 & 38.14 & 5.33 & 168.00 & 2.91 & 2.50 & 0.67 \\
\hline & 50 & 7.89 & 1.26 & 41.85 & 5.87 & 172.00 & 3.05 & 2.60 & 0.73 \\
\hline & 75 & 7.85 & 1.19 & 45.21 & 5.95 & 178.00 & 3.12 & 2.69 & 0.74 \\
\hline & 100 & 7.82 & 1.15 & 46.20 & 6.08 & 183.00 & 3.20 & 2.92 & 0.79 \\
\hline \multicolumn{2}{|l|}{ Mean } & & 1.23 & 42.85 & 5.81 & 175.25 & 3.07 & 2.68 & 0.73 \\
\hline \multicolumn{2}{|c|}{ LSD. 0.05 Amendments } & --- & 0.012 & 1.34 & 0.41 & 1.58 & 1.116 & ns & 0.011 \\
\hline \multicolumn{2}{|c|}{ LSD. 0.05 Rates of N } & ---- & 0.022 & 1.82 & 0.42 & 1.41 & 0.118 & 0.12 & 0.016 \\
\hline \multicolumn{2}{|c|}{ LSD. 0.05 Interaction } & --- & $*$ & $\mathrm{~ns}$ & ns & $*$ & ns & ns & $* * *$ \\
\hline
\end{tabular}


Mohamed et al., (2019) reveal that the EC values treatments tended to decrease when soil was treated with mineral fertilizers combined with bio-fertilizers compared to soil treated with mineral fertilizers alone. These bio-fertilizers provided a substantial modification of soil physical properties, especially soil structure as well as soil aggregation and drainable pores. Consequently, these favorable conditions can positively affect soil permeability and encourage the downward movement of leaching water.

\section{Availability macronutrients in the studied soils}

Data in Table (4) showed that the available macronutrients (N, P and $\mathrm{K}$ ) in soil was affected by soil amendments combined with nitrogen fertilizer rates. Generally, it is clear from Table 4 that soil treated with compost combined with nitrogen had high available $\mathrm{N}$, $\mathrm{P}$ and $\mathrm{K}$. The high of mean values of $\mathrm{N}, \mathrm{P}$ and $\mathrm{K}$ contents in soil was $44.04,5.93$ and $177.00 \mathrm{mg} / \mathrm{kg}$ soil for soil treated by compost together nitrogen mineral fertilizer rates than other treatments. The effect of soil amendments alone or combined with different rates of mineral $\mathrm{N}$ on available $\mathrm{N}, \mathrm{P}$ and $\mathrm{K}$ were significantly increased with increasing rate nitrogen mineral. The interaction between soil amendments and different rates of mineral $\mathrm{N}$ were not significant on $\mathrm{N}$ and $\mathrm{P}$, while that of $\mathrm{K}$ was significant increase. The corresponding relative increases of mean values were $12.31,1.91$ and $2.88 \%$ for $\mathrm{N}, \mathrm{P}$ and $\mathrm{K}$ contents in soil treated with nitrogen mineral fertilizer different rates compared without nitrogen mineral. On the other hand, the relative increases of mean values were 12.26 for $\mathrm{N}, 8.95 \%$ for $\mathrm{P}$ and $3.74 \%$ for $\mathrm{K}$ content in soil treated with biochar combined with different nitrogen mineral rates compared with biochar alone. The relative increases of mean values available $\mathrm{N}, \mathrm{P}$ and $\mathrm{K}$ contents in soil treated with compost together nitrogen mineral rates were $11.72 \%$ for $\mathrm{N}, 10.22 \%$ for $\mathrm{P}$ and $4.73 \%$ for $\mathrm{K}$ respectively, compared with compost alone. As well as, the relative increases of mean values were $12.35 \%$ for $\mathrm{N}, 9.01 \%$ for $\mathrm{P}$ and $4.32 \%$ for $\mathrm{K}$ contents in soil treated with bio-fertilizer combined with nitrogen mineral rates compared with bio-fertilizers alone.

The distribution pattern of the amounts of available $\mathrm{N}, \mathrm{P}$ and $\mathrm{K}$ in soil can be arranged in the order: for $\mathrm{N}$

Bio-fertilizer > Mineral N rates > Biochar > compost

Compost $>$ bio-fertilizer $>$ biochar $>$ mineral $\mathrm{N}$ rates for $\mathrm{P}$ and $\mathrm{K}$ content in soil compared without mineral $\mathrm{N}$ fertilizer. These results are in agreement with those reported (Liang et al., 2006) who indicated that addition of biochar led to increased content N, P and $\mathrm{K}$ in soil. Hafez (2014) reported that the application of biofertilizers on available contents of $\mathrm{N}, \mathrm{P}$ and $\mathrm{K}$ in the soil after harvest was increase. (Ghosh et al., 2015) found the increases in available soil nutrients $(\mathrm{N}, \mathrm{P}, \mathrm{K}, \mathrm{Ca}$ and $\mathrm{Mg}$ ) resulting due to the biochar and compost application. Biochar addition to soil led to an increase of organic matter, water holding capacity, nutrientretaining capacity, and bioavailability nutrition elements (e.g., N, P, K, Ca) in soil (Ouyang et al., 2013). The used of bio-fertilizer was increased of the availability of soil organic matter, and the bioavailability nutrition elements may be due to enhance the microbial activities and thereby the soil aggregate formation and stability.

\section{Available micronutrients content in soil ( $\mathrm{mg} / \mathrm{kg}$ soil)}

Data in Table (4) showed the amounts of available $\mathrm{Fe}, \mathrm{Mn}$ and $\mathrm{Zn}$ in soil which are increased as affected by all treatments. Bio-fertilizers including Azospirillum brasilense, compost and biochar in combination with mineral fertilizers, may have positive impact on bioavailability and mobility of micronutrients in soil, depending on the chemical nature of metals. This is more related to the residual of organic compounds that are directly decomposed after different biochemical and chemical changes, which led to the release of more available microelements. The application of soil amendments was significant for $\mathrm{Fe}$ and $\mathrm{Zn}$, while the Mn was no significant. The different application rates of nitrogen fertilizer significantly increased $\mathrm{Fe}, \mathrm{Mn}$ and $\mathrm{Zn}$ contents in soil. The interaction between soil amendments and different nitrogen mineral rates were significant for $\mathrm{Zn}$ with increasing rate of nitrogen, while the Fe and Mn showed not significant. These results are in agreement with those Mohamed et al (2019) reported that the interaction between bio-fertilizer and mineral fertilizers on available $\mathrm{Zn}$ contents in soil was significant, while the effect on Fe was not significant. Shaban and Attia (2009) found that the content of available $\mathrm{Fe}, \mathrm{Mn}, \mathrm{Zn}$ and $\mathrm{Cu}(\mathrm{mg} / \mathrm{kg})$ in soil after maize harvest were insignificantly increased as affected by bio-fertilizers including Azospirillum brasilense in combination with chemical fertilizers, may have positive impact on bio-availability and mobility of micronutrients in soil, depending on the chemical nature of metals.

It may be concluded, therfore that compost, biochar and bio-fertilizer combined with nitrogen mineral applications decreased soil $\mathrm{pH}$ and $\mathrm{EC}$, while increased the contents of $\mathrm{N}, \mathrm{P}, \mathrm{K}, \mathrm{Fe}, \mathrm{Mn}$ and $\mathrm{Zn}$.

\section{Effect of soil amendments on Maize productivity}

Data presented in Table (5) Showed that the effect of biochar, compost and bio-fertilizer combined with different nitrogen mineral rates on plant plant height $(\mathrm{cm})$, weight of 100 grains $(\mathrm{g})$, weight of stover (ton/fed), weight of ear (ton/fed) and weight of grains yield (ton/fed) were increased with increasing nitrogen 
mineral rates except plants treated with bio-fertilizer. Albert and Kawame (2018) indicated that application of biochar and/or compost resulted in significant increases in the number of plant leaves, plant height and maize crop growth.

Shaban and Omar (2006) reported that application of bi-fertilizer combined with $75 \%$ nitrogen mineral fertilizer increased the weight of 100 grains, weight of stover and grains yield than without bio-fertilizer. The application of soil amendments and different rates of nitrogen mineral fertilizer significantly increased of plant plant height $(\mathrm{cm})$, weight of 100 grains $(\mathrm{g})$, weight of stover (ton/fed), weight of Ear (ton/fed) and weight of grains yield (ton/fed). As well as, the interaction between soil amendments and different rates of nitrogen mineral fertilizer were significant plant height $(\mathrm{cm})$, weight of ears (ton/fed) and weight of grains yield (ton/fed), while the weight of 100 grains (g) and weight of stover (ton/fed) were no significant. In addition the relative increases of mean values were $17.02 \%$ for plant height $(\mathrm{cm}), 18.65 \%$ for weight of 100 grains $(\mathrm{g})$; $43.97 \%$ for weight of stover yield (ton/fed) ; $45.60 \%$ for weight of ears (ton/fed) and $87.62 \%$ for weight of grains yield (ton/fed) respectively for soil treated with biochar combined different nitrogen rates compared with control. Also, the relative increases of mean values were $26.60 ; 25.76 ; 47.67 ; 47.86$ and $90.48 \%$ for plant height $(\mathrm{cm})$, weight of 100 grains $(\mathrm{g})$, weight of Stover (ton/fed), weight of Ear (ton/fed) and weight of grains yield (ton/fed) respectively, as affected with compost compared with control. On the other hand the relative increases of mean values were $22.87 ; 23.08 ; 44.36$; 46.11 and $88.57 \%$ for plant height $(\mathrm{cm})$, weight of 100 grains (g), weight of stover yield (ton/fed), weight of ears yield (ton/fed) and weight of grains yield (ton/fed) respectively, as affected with bio-fertilizer compared with control. Therefore, it can categorize the beneficial effects of the used soil amendments on the studied crop of maize into different orders according the amounted increases in maize parameters, as follows: Compost $>$ bio-fertilizer> biochar > control, for plant height $(\mathrm{cm})$, weight of 100 grains $(\mathrm{g})$, weight of Stover (ton/fed), weight of Ear (ton/fed) and weight of grains yield (ton/fed) respectively. Application of compost and biochar significantly increased plant height $(\mathrm{cm})$ and biomass of maize (Abdullah and Gill, 2016).

Table 5. Yield and yield components of maize after harvesting

\begin{tabular}{|c|c|c|c|c|c|c|}
\hline Soil amendments & $\begin{array}{c}\text { Rates of N } \\
\text { (kg/fed) }\end{array}$ & $\begin{array}{l}\text { Plant height } \\
\text { (cm) }\end{array}$ & $\begin{array}{c}\text { Weight of } 100 \\
\text { grains (g) }\end{array}$ & $\begin{array}{c}\text { Weight of } \\
\text { stover } \\
\text { (ton/fed) }\end{array}$ & $\begin{array}{c}\text { Weight of } \\
\text { Ear } \\
\text { (ton/fed) }\end{array}$ & $\begin{array}{c}\text { Weight of } \\
\text { grains yield } \\
\text { (ton/fed) }\end{array}$ \\
\hline \multirow{4}{*}{ Control } & 0 & 158.00 & 22.58 & 0.84 & 0.95 & 0.83 \\
\hline & 50 & 185.00 & 28.30 & 3.02 & 2.18 & 1.04 \\
\hline & 75 & 198.00 & 32.14 & 3.14 & 2.25 & 1.07 \\
\hline & 100 & 211.00 & 36.20 & 3.29 & 2.34 & 1.28 \\
\hline \multirow[t]{2}{*}{ Mean } & & 188.00 & 29.81 & 2.57 & 1.93 & 1.05 \\
\hline & 0 & 194.00 & 25.69 & 1.89 & 0.98 & 0.86 \\
\hline \multirow{3}{*}{ Biochar } & 50 & 210.00 & 33.48 & 4.15 & 3.29 & 2.19 \\
\hline & 75 & 235.00 & 40.10 & 4.32 & 3.43 & 2.35 \\
\hline & 100 & 242.00 & 42.20 & 4.45 & 3.55 & 2.47 \\
\hline Mean & & 220.00 & 35.37 & 3.70 & 2.81 & 1.97 \\
\hline \multirow{4}{*}{ Compost } & 0 & 212.00 & 26.90 & 1.92 & 0.98 & 0.87 \\
\hline & 50 & 239.00 & 37.20 & 4.19 & 3.33 & 2.20 \\
\hline & 75 & 246.00 & 42.36 & 4.48 & 3.47 & 2.39 \\
\hline & 100 & 255.10 & 43.55 & 4.59 & 3.62 & 2.53 \\
\hline Mean & & 238.00 & 37.49 & 3.80 & 2.85 & 2.00 \\
\hline \multirow{4}{*}{ Biofertilizer } & 0 & 198.00 & 25.95 & 1.91 & 0.98 & 0.86 \\
\hline & 50 & 238.00 & 36.85 & 4.12 & 3.30 & 2.29 \\
\hline & 75 & 254.00 & 42.15 & 4.45 & 3.59 & 2.43 \\
\hline & 100 & 233.00 & 41.79 & 4.35 & 3.40 & 2.33 \\
\hline Mean & & 231.00 & 36.69 & 3.71 & 2.82 & 1.98 \\
\hline LSD. 0.05 Amendments & & 2.57 & 2.13 & 0.30 & 0.032 & 0.036 \\
\hline LSD. 0.05 Rates of N & & 2.93 & 1.68 & 0.47 & 0.038 & 0.060 \\
\hline LSD. 0.05 Interaction & & $* * *$ & ns & ns & $* * *$ & $* * *$ \\
\hline
\end{tabular}


Furthermore, the increments in plant growth due to biofertilizers application might be a result of the vital role of bacteria that present in the applied biofertilizer in producing some hormone substances, i.e. gibberellins, auxins and cytokines. PGPR is positive effect on plant growth by direct mechanisms such as solubilization of nutrients, nitrogen fixation, production of growth regulators, etc., or indirectly such as competitive exclusion of pathogens or removal of phytotoxic substances (Bashan and de-Bashan, 2010). Biochar combined with mineral fertilizer significantly increased plant growth, then chemical fertilizer alone (Biederman and Harpole, 2013). Steiner et al. (2007) indicated that an increase of maize grain yield using biochar combined with NPK fertilizer compared to use of NPK fertilizer alone. From these result could be attributed to used of biochar, compost and bio-fertilizer combined with $\mathrm{N}$ mineral fertilizer including improvement in soil structure, soil health, microbial activity and nutrient availability through a variety of mechanisms.

\section{Macronutrients concentration in grains}

Data presented in Table (6) illustrated data of macronutrients concentration in Stover and grains maize under different soil amendments alone or combined with nitrogen mineral fertilizer different rates. The data obtained of $\mathrm{N}, \mathrm{P}$ and $\mathrm{K}$ concentration (\%) by maize stover and grains show increase with increasing nitrogen mineral rates combined with soil amendments. These increases were cleared with high application rates of added mineral fertilizers. Also, these increases were cleared with combination biochar and compost compared with bio-fertilizer and mineral fertilizers alone. The effect of soil amendments application was significantly increased of $\mathrm{N}, \mathrm{P}$ and $\mathrm{K}$ concentrations in stover and grains. On the other hand, the different rates of nitrogen mineral application was increased of $\mathrm{N}, \mathrm{P}$ and $\mathrm{K}$ concentrations in stover, while the $\mathrm{P}$ and $\mathrm{K}$ concentration in grains were significantly increases with increasing of nitrogen mineral fertilizer rate. Also, the interaction between soil amendments and nitrogen mineral fertilizer rates were significantly of $\mathrm{N}$ and $\mathrm{K}$ concentrations in stover, while the $\mathrm{N}, \mathrm{P}$ and $\mathrm{K}$ concentrations in grains were no significant. This result may be due to the role of the used bio-fertilizers in fixing of atmospheric $\mathrm{N}$ and transferring insoluble $\mathrm{P}$ in the soil to soluble form for absorption and uptake by plants (El-Habbasha et al., 2007).

Table 6. Macronutrients concentration in stover and grains in maize plants

\begin{tabular}{|c|c|c|c|c|c|c|c|}
\hline \multirow{3}{*}{ Soil amendments } & \multirow{3}{*}{$\begin{array}{c}\text { Rates of N } \\
(\mathbf{k g} / \mathrm{fed})\end{array}$} & \multicolumn{6}{|c|}{ Macronutrients concentration (\%) } \\
\hline & & \multicolumn{2}{|c|}{$\mathbf{N}$} & \multicolumn{2}{|c|}{$\mathbf{P}$} & \multicolumn{2}{|c|}{$\mathbf{K}$} \\
\hline & & Stover & Grains & Stover & Grains & Stover & Grains \\
\hline \multirow{4}{*}{ Control } & 0 & 0.98 & 1.14 & 0.21 & 0.35 & 2.33 & 1.10 \\
\hline & 50 & 2.03 & 1.18 & 0.24 & 0.39 & 2.36 & 1.15 \\
\hline & 75 & 2.07 & 1.22 & 0.28 & 0.43 & 2.37 & 1.20 \\
\hline & 100 & 2.13 & 1.26 & 0.30 & 0.45 & 2.42 & 1.23 \\
\hline \multirow[t]{2}{*}{ Mean } & & 1.80 & 1.20 & 0.26 & 0.41 & 2.37 & 1.17 \\
\hline & 0 & 1.04 & 1.19 & 0.23 & 0.37 & 2.36 & 1.12 \\
\hline Di & 50 & 2.12 & 1.25 & 0.25 & 0.44 & 2.43 & 1.19 \\
\hline Biochar & 75 & 2.18 & 1.30 & 0.29 & 0.48 & 2.49 & 1.23 \\
\hline & 100 & 2.22 & 1.34 & 0.33 & 0.53 & 2.52 & 1.31 \\
\hline \multirow[t]{2}{*}{ Mean } & & 1.89 & 1.27 & 0.28 & 0.46 & 2.45 & 1.21 \\
\hline & 0 & 1.07 & 1.20 & 0.24 & 0.39 & 2.38 & 1.14 \\
\hline \multirow{3}{*}{ Compost } & 50 & 2.16 & 1.28 & 0.29 & 0.45 & 2.47 & 1.25 \\
\hline & 75 & 2.23 & 1.36 & 0.33 & 0.53 & 2.55 & 1.36 \\
\hline & 100 & 2.27 & 1.42 & 0.37 & 0.57 & 2.59 & 1.41 \\
\hline \multirow[t]{2}{*}{ Mean } & & 1.93 & 1.32 & 0.31 & 0.49 & 2.50 & 1.29 \\
\hline & 0 & 1.05 & 1.17 & 0.22 & 0.38 & 2.37 & 1.13 \\
\hline \multirow{3}{*}{ Biofertilizer } & 50 & 2.14 & 1.27 & 0.27 & 0.43 & 2.49 & 1.21 \\
\hline & 75 & 2.24 & 1.38 & 0.35 & 0.50 & 2.57 & 1.35 \\
\hline & 100 & 2.20 & 1.36 & 0.32 & 0.54 & 2.50 & 1.30 \\
\hline Mean & & 1.91 & 1.30 & 0.29 & 0.46 & 2.48 & 1.25 \\
\hline LSD. 0.05 Amendments & & 0.12 & 0.11 & 0.02 & 0.016 & 0.03 & 0.06 \\
\hline LSD. 0.05 Rates of N & & 0.14 & ns & 0.015 & 0.017 & 0.028 & 0.08 \\
\hline LSD. 0.05 Interaction & & ** & ns & ns & ns & $*$ & ns \\
\hline
\end{tabular}


The relative increases of mean values were 5.00, 7.69 and $3.38 \%$ for $\mathrm{N}, \mathrm{P}$ and $\mathrm{K}$ concentrations in stover and 5.83, 12.20 and $3.42 \%$ for $\mathrm{N}, \mathrm{P}$ and $\mathrm{K}$ concentrations in grains of maize as affected with biochar alone or combination of nitrogen mineral fertilizer rates compared with nitrogen mineral different rates (control). The corresponding relative increases of mean values were $7.22,19.23$ and $10.26 \%$ for $\mathrm{N}, \mathrm{P}$ and $\mathrm{K}$ concentrations in Stover and 10.00, 19.51 and 10.26 $\%$ for $\mathrm{N}, \mathrm{P}$ and $\mathrm{K}$ concentrations in grains respectively, as affected with compost with or without nitrogen mineral fertilizer different rates. The relative increases of mean values were $6.11,11.54$ and $4.64 \%$ for $\mathrm{N}, \mathrm{P}$ and K concentrations in Stover and 8.33, 12.20 and 6.84 $\%$ for $\mathrm{N}, \mathrm{P}$ and $\mathrm{K}$ concentrations in grains maize plants as affected with bio-fertilizer respectively, compared with nitrogen mineral rates (control).

It is evident from the distribution patterns of $\mathrm{N}, \mathrm{P}$ and $\mathrm{K}$ concentrations by both (Stover and grains) maize that it could be arranged according to their contents in the following orders:

Compost > biofertilizer > biochar > control for Stover and grains.
These results are in agreement by Shah et al., (2007) found composted manure combined with $\mathrm{N}$ and $\mathrm{P}$ fertilizers enhanced plant growth and nutrient uptake as compared to control. Meena et al (2013) reveled that the Azotobacter inoculation combined with mineral fertilizer rates was increased of $\mathrm{N}, \mathrm{P}$ and $\mathrm{K}$ uptake in grains maize compared with control. Biochar amendment on different soils has led to increase availability and uptake of nutrients by plants (Hass et al., 2012).

\section{Micronutrients concentrations in stover and grains of maize plant}

Data presented in Table (7) showed that the effects of applied soil amendments alone or combination different rates of nitrogen mineral fertilizer on some micronutrients ( $\mathrm{Fe}, \mathrm{Mn}$ and $\mathrm{Zn} \mathrm{mg} / \mathrm{kg}$ ) in stover and grains of maize plants caused markedly increases with increasing of nitrogen mineral fertilizer rates. Application of soil amendments to maize plants was significant of $\mathrm{Mn}$ and $\mathrm{Zn}$ for stover and the $\mathrm{Fe}, \mathrm{Mn}$ and $\mathrm{Zn}$ concentrations in grains were significant. The different rates of nitrogen mineral fertilizer had significant effect on $\mathrm{Mn}$ and $\mathrm{Zn}$ of stover and $\mathrm{Fe}$ and $\mathrm{Zn}$ concentration in grains.

Table 7. Macronutrients concentration in stover and grains in maize plants

\begin{tabular}{|c|c|c|c|c|c|c|c|}
\hline \multirow{3}{*}{ Soil amendments } & \multirow{3}{*}{$\underset{\text { (kg/fed) }}{N}$} & \multicolumn{6}{|c|}{ Micronutrients concentration (mg/kg) } \\
\hline & & \multicolumn{2}{|c|}{$\mathbf{F e}$} & \multicolumn{2}{|c|}{ Mn } & \multicolumn{2}{|c|}{ Zn } \\
\hline & & Stover & Grains & Stover & Grains & Stover & Grains \\
\hline \multirow{4}{*}{ Control } & 0 & 85.34 & 46.35 & 62.15 & 29.34 & 16.52 & 31.05 \\
\hline & 50 & 89.14 & 52.17 & 65.32 & 32.14 & 18.95 & 33.52 \\
\hline & 75 & 93.74 & 55.63 & 68.12 & 36.52 & 20.36 & 36.52 \\
\hline & 100 & 98.71 & 58.31 & 69.31 & 38.10 & 22.41 & 37.46 \\
\hline \multicolumn{2}{|c|}{ Mean } & 91.73 & 53.12 & 66.23 & 34.03 & 19.56 & 34.64 \\
\hline \multirow{4}{*}{ Biochar } & 0 & 96.27 & 48.20 & 72.35 & 32.41 & 18.95 & 33.52 \\
\hline & 50 & 104.32 & 55.63 & 75.86 & 34.62 & 22.36 & 38.96 \\
\hline & 75 & 112.50 & 59.67 & 79.34 & 39.52 & 25.14 & 42.35 \\
\hline & 100 & 117.34 & 63.24 & 82.14 & 42.18 & 28.14 & 44.52 \\
\hline \multicolumn{2}{|c|}{ Mean } & 107.61 & 56.69 & 77.42 & 37.18 & 23.65 & 39.84 \\
\hline \multirow{4}{*}{ Compost } & 0 & 98.34 & 49.34 & 71.35 & 31.65 & 17.63 & 32.85 \\
\hline & 50 & 113.10 & 57.63 & 73.65 & 33.48 & 20.88 & 37.96 \\
\hline & 75 & 118.34 & 61.48 & 77.90 & 38.75 & 24.32 & 39.85 \\
\hline & 100 & 123.00 & 65.34 & 80.15 & 41.95 & 26.52 & 42.35 \\
\hline \multicolumn{2}{|c|}{ Mean } & 113.20 & 58.45 & 75.76 & 36.46 & 22.34 & 38.25 \\
\hline \multirow{4}{*}{ Biofertilizer } & 0 & 97.63 & 48.52 & 70.52 & 30.85 & 16.39 & 31.97 \\
\hline & 50 & 110.52 & 55.34 & 72.36 & 32.65 & 20.14 & 36.87 \\
\hline & 75 & 120.48 & 63.85 & 75.95 & 37.52 & 23.10 & 43.55 \\
\hline & 100 & 116.85 & 61.52 & 79.38 & 40.19 & 25.93 & 40.88 \\
\hline \multicolumn{2}{|c|}{ Mean } & 111.37 & 57.31 & 74.55 & 35.30 & 21.39 & 38.32 \\
\hline \multicolumn{2}{|c|}{ LSD. 0.05 Amendments } & ns & 1.80 & 1.50 & 2.14 & 2.60 & 1.33 \\
\hline \multicolumn{2}{|c|}{ LSD. 0.05 Rates of N } & ns & 2.25 & 0.75 & ns & 0.91 & 0.37 \\
\hline \multicolumn{2}{|l|}{ LSD. 0.05 Interaction } & ns & Ns & $\mathrm{ns}$ & ns & ns & ns \\
\hline
\end{tabular}


The interaction between soil amendments and different rates of nitrogen mineral fertilizer had non significant affect on $\mathrm{Fe}, \mathrm{Mn}$ and $\mathrm{Zn}$ concentrations in stover and grains of maize. The relative increases of mean values were $17.31,16.90$ and $20.91 \%$ for $\mathrm{Fe}, \mathrm{Mn}$ and $\mathrm{Zn}$ concentration in stover and 6.72, 9.26 and $15.01 \%$ for $\mathrm{Fe}, \mathrm{Mn}$ and $\mathrm{Zn}$ respectively, concentrations in grains maize as affected with biochar with or without nitrogen mineral fertilizer rates than control. The corresponding relative increases of mean values micronutrients concentration in stover and grains were 23.41, 14.39 and $14.21 \%$ in stover and 10.03, 7.14 and $10.42 \%$ in grains respectively as affected of compost combined with or without nitrogen mineral fertilizer rates compared with control. The relative increases of mean values were $21.41,12.26$ and $9.36 \%$ concentrations in stover and 7.89, 3.73 and $10.62 \%$ concentrations in grains respectively, as affected with bio-fertilizer alone or combined with nitrogen mineral rates compared with control.

It is evident from the concentrations distribution patterns of $\mathrm{Fe}, \mathrm{Mn}$ and $\mathrm{Zn}$ that it could be arranged in the order stover and Grains into following orders: Compost $>$ bio-fertilizer $>$ biochar $>$ control for $\mathrm{Fe}$ in stover and grains. Biochar $>$ Compost $>$ bio-fertilizer $>$ control for Mn and $\mathrm{Zn}$ concentrations in stover. Biochar $>$ compost > bio-fertilizer > control for $\mathrm{Mn}$ concentration in grains. Biochar > bio-fertilizer > compost $>$ control for $\mathrm{Zn}$ concentration in grains. The activity of these bacteria in the absorption zone of plant roots might improve soil fertility and consequently plant development by $\mathrm{N}$-fixation and due to releasing of certain other nutrients, i.e. $\mathrm{Fe}, \mathrm{Zn}$ and $\mathrm{Mn}$ (Youseef et al., 2017). Ahmed et al., (2012) found that the addition of biofertilizers significantly increased micronutrients content of corn plants in comparison to salinity treated plants. Microorganisms that dwell on the expense of organic matter originating from the exogenous sources or derived from root activity of plants are the agents of nutrient release and mobilization besides performing many other functions in the soil (Abdullha and Gill, 2016). It can be concluded that the concentrations of micronutrients in plants, generally, reflect their available contents in soil and long leaching period under different water resources used. This result may be due to the role of soil amendments in improving the soil microbial activity in releasing nutrients required for plant growth.

\section{CONCLUSIONS}

The obtained results showed that improved of soil, growth and yield of maize were influenced by different soil amendments combined with nitrogen mineral fertilizer rates. The application of soil amendments increased growth characters and grain yield of maize and improved chemical and physical properties of soil.

\section{REFERENCES}

Abd El-Hadi. 2004. Country Report on Egytian Agriculture. IPI regional workshop on Potassium and Fertigation development in West Asia and North Africa; Rabat, Morocco. November. 24-28

Abdelraouf, R. E., E. F. Essay and M. S. Saleh. 2017. Sustainable management of deficit irrigation in sandy soils by production biochar and adding it as a soil amendment. Middle East J. of Agric. 6 (4): 1359- 1375.

Abdullha, A. and S. Gill. 2016. Integrated plant nutrient management for sandy soil using chemical fertilizers, compost, biochar and biofertilizers Case Study in UAE. J. of Arid Land Studies. 26 (3): 101 - 106.

Ahmed, M. M., N. O. Fathi, M. K. Mahrous and E. E. Ashraf. 2012. Synergistic effects of biofertilizers and antioxidants on growth nutrients content of corn under salinity and water deficit stresses. Alexandria Sci. Exchange J. .33 (4): $292-304$.

Albert, K. M. and A. F. Kwame. 2018. Biochar and or compost applications improve soil properties, growth and yield of maize grown in Acidic rainforest and coastal savannah soils in Ghana, Research Article. Inter. J. of Agron. 6 - 8.

Atanu, M. and L. Rattan. 2013. Biochar impacts on soil physical properties and greenhouse gas emissions. J. Agronomy. 3: 313- 339.

Bashanm, Y. and L.E. de-Bashan. 2010. How the plant growth promoting bacterium Azospirillum promotes plant growtha critical assessment. Adv. Agron. 108:77-136.

Biederman, L.A. and W. S. Harpole. 2013. Biochar and its effects on plant productivity and cycling: a meta-analysis. G.C.B. Bioenergy. 5:202 - 214

Brunner, P. H. and H. R. Wasmer. 1978. Methods of analysis of sewage sludge solid wastes and compost. W.H.O. International Reference Center for Wastes Disposal (H8600), Dulendr of Switzerland.

Chapman, H.D. and P.F. Pratt. 1961. "Methods of Analysis for Soils, Plants and Water". Agric. Publ. Univ., of California, Riverside

Cláudio, P. J, C. N. Clésia, L. F. Renildes, R. C. Paulo and L. P. José. 2007. Effects of composted urban solid waste addition on yield and metal contents of lettuce. J. Brazil Chem Soci. 18 (1):195- 204.

Cottenie, A., M. Verloo, L. Kikens, G. Velghe and R. Camerlynck. 1982. Analytical Problems and Method in Chemical Plant and Soil Analysis. Hand book Ed. A. Cottenie, Gent, Belgium.

Downie, A., A. Crosky, P. Munroe. 2009. Physical properties of biochar. In J.Lehmann, S. Joseph eds., Biochar for environmental management: Sci. and technology. Earthscan, London. 13-32. 
Duarte, S. J., G. Bruno and E. P. Carlos. 2019. Effect of biochar particle size on physical, hydrological and chemical properties of loamy and sandy tropical soils. J. Agronomy. 9: 1 - 15 .

El-Habbasha, S.F., M. Hozayn and M.A. Khalafallah. 2007. Integration effect between phosphoruslevels and biofertilizers on quality and quality yield of faba bean (Viciafaba, L.) in newly cultivated sand soils. Res. J. Agric. Biol. Sci., 3 (6):966 - 971

El-Hosary, A. A., Y. H.Gaber, M. M. E. El-Saeed and E. S. Mohamed. 2019. Response of white maize hybrids to plant densities and nitrogen fertilizer rates. Annals of Agric. Sci. Moshtohor. 57 (2): 333- 350.

Hafez, W.A. 2014. Create environmental conditions for sugar beet production by adding bio and organic fertilizer under Hewly reclaimed saline soil in North Sinai. J. Soil Sci. and Agric. Eng. Mansoura Univ. 5(11):1571-1584.

Hass, A.m., J. M. Gonzalez, I. M. Lima, H. W. Godwin, J. J. Halvorson and D. G. Boyer. 2012. Chicken manure biochar as liming and nutrient source for acid Appalachian soil. J. of Environmental Quality. 41(4): 1096-1106.

Ghosh, S., L. Fern ow and B. Wilson. 2015. Influence of biochar and compost on soil properties and tree growth in a tropical urban environment. Intr. J. Environ. Sci. Technol.12: 1303-1310.

Gomez, K.A. and A.A. Gomez. 1984. Statistics for Agriculture Research. $2^{\text {nd }}$ Ed. John Willey and sons, New York, USA.

Idriss, M. AL-Turk. 2004. The Ability of Some ThermoAlkalophilic Bacillus Species to Fix Nitrogen, Isolated from Madinah Munawwarah Soils, Saudi Arabia.J. Jkau Sci. 16: 3-8.

Jha, P., A.K. Biswas, B.L. Lakaria and A.Subba Rao. 2010. Biochar in agriculture - prospects and related implications. Curr. Sci. 99:1218-1225.

Jones, D.L., J. Rousk, G. Edwards-Jones, T.H. DeLuca and D.V. Murphy. 2011. Biochar-mediated changes in soil quality and plant growth in a three-year field trial. Soil Biol Biochem. 12: 1- 10.

Khaled, D. A. and J. S. Jeff. 2019. Addition of biochar to a sandy desert soil: Effect on crop growth, water retention and selected properties. J. Agronomy. 9(327):1-24.

Klute, A. 1986. Methods of Analysis. Part 1, Soil Physical Properties. ASA and SSSA, Madison, WI.

Lehmann, J. and S. Joseph. 2009. Biochar for environmental management: an introduction. In: J. Lehmann, S. Joseph. (eds.), Biochar for Environmental Management: Sci. and Technology, Earthscan, London. 1-12.

Lei, O., and R. Zhang. 2013. Effects of biochars derived from different feedstocks and pyrolysis temperatures on soil physical and hydraulic properties. J. of Soils and Sediments. 13(9): 1561-1572.

Leonard, G. 2013. Effect of biochar application rate on soil physical and hydraulic properties of a sandy loam. Archives of Agronomy and Soil Sci. 27: 37- 41.
Liang, B., J. Lehmann, D. Solomon, J. Kinyangi, J. Grossman, B. O'Neill, J.O.Skjemstad, J.Thies, F.J.Luizão, J.Petersen and E.G. Neves. 2006. Black carbon increases cation exchange capacity in soils. Soil Sci. Soc. Am. J. 70:17191730.

Meena, M. D., D.D.Tiwari, S. K.Chaudhari, D.R. Biswas, B.Narjary, A. L. Meena, B.L. Meena and R. B. Meena. 2013. Effect of biofertilizer and nutrient levels on yield and butrient uptake by maize (Zea mays L.). Annals of Agric-Bio Res. 18 (2): 176- 181.

Mohamed, E. S., A.A.El-Hosary, G. Y. Hammam, M .E. ElSaeed and A. A. El-Hosary. 2019. Maize hyprids yield potential as affected by plant population denstity in Qalyubia, Egypt. Bioscience Res. 16 (2): 1565- 1576.

Mohamed, I.M., M. H. Kenawy and Kh. A. H. Shaban. 2019. Role of mineral and bio-fertilizers on some soil properties and rice productivity under reclaimed saline soils. Asian Soil Res. J. 2 (1): 1- 12.

Muhammad, A. N., K.h.Muhammad, A. Muhammad and A. Ghulam. 2017. Combined application of biochar with compost and fertilizer improves soil properties and grain yield of maize. J. of Plant Nutri. 41 (1): 112- 122.

Nasef, M.M., Kh.A. Shaban and A. E. Amal. 2009. Effect of compost, compost tea and bio fertilizer application on some soil chemical properties and rice productivity under saline soil condition. J. Agric. Mansoura Unv. 34(4):26092623.

Ouda, S. A. and T. Noreldin. 2016. Solutions for maize production consumption gap in Egypt. Conference: 4th African Regional Conferences on Irrigation and Drainage (ARCID), At Aswan, Egypt

Ouyang, L., F.Wang, J. Tang, L. Yu. and R. Zhang. 2013). Effect of biochar amendment on soil aggregates and hydraulic properties. J. of Soil Sci. and Plant Nutr. 13 (4): 991- 1002.

Page, A.L., R.H. Miller and D.R.Keeney. 1982. "Methods of Chemical Analysis". Part 2: Chemical and microbiological properties (Second Edition).American Society of Agronomy, Inc. and Sci. Soc. of America, Inc. Publishers, Madison, Wisconsin U.S.A.

Paulin, B. and O.M. Peter. 2008. Compost Production and Use in Horticulture. Western Australian Agri. Authority, Bulletin 4746.

Rajput, L., A. Imran, F. Mubeen and F. Y. Hafeez. 2013. Salttolerant PGPR planococcus rifietoensis promots the growth and yield of wheat (Triticum Aestivum L.) cultivated in saline soil. Pak. J. Bot. 45 (6): 1955- 1962

Salimpour, S., K. Khavazi, H. Nadian H. Besharati and M. Miransari. 2010. Enhancing phosphorous availability to canola (Brassica napus L.) using P solubilizing and sulfur oxidizing bacteria. Australian J. Crop Sci. 4(5): 330-337.

Shaban, Kh. A. and M. A. Attia. 2009. Evaluation of bio-and chemical fertilizers applied to corn growth on a saline sandy soil. Minufiya J. Agric. Res. 34 (3): 1311- 1326.

Shaban, Kh. A. and M.N.A. Omar. 2006. Improvement of maize yield and some soil properties by using nitrogen mineral and PGPR group fertilization in newly cultivated saline soils. Egypt. J. Soil, Sci. 46(3): 329 - 342. 
Shah, Z., Z. Shah, M. Tariq and M.Afzal. 2007. Response of maize to integrated use of compost and urea fertilizers. Sarhad J. Agric. 23(3): 667-673.

Simon, K., L.Hongzhen, L.Jiaxin, B.Hamidou, D.Renjie and W. Shubio. 2019. Role of nutrient Enriched biochar as a soil amendment during maize growth: Exploring practical alternatives to recycle agricultural residuals and to reduce chemical fertilizer demand. Sustainability J.11: 1 - 22

Steiner, C.W.G., J.Teixeira, T.Lehmann, J.L.V.Nehls, D.Macêdo, W.E.H. Blum and W. Zech. 2007. Long term effects of manure, charcoal and mineral fertilization on crop production and fertility on a highly weathered Central Amazonian upland soil. Plant and Soil. 291: 275-290.
Tomasz, G., P. Joanna, Z.Tomasz and G. Krzysztof. 2016. Effect of biochar application on soil hydrological properties and physical quality of sandy soil. J. Geoderma. 281: 1- 20.

Wu, S.C., Y.M. Luo, K.C. Cheung and M.H. Wong. 2006 Influence of bacteria on $\mathrm{Pb}$ and $\mathrm{Zn}$ speciation, mobility and bio-availability in soil. Environmental Pollution. 144 (3): $765-773$.

Youssef, M.E.A., I.A.S. Al-Easily and A. S. Nawar. 2017. Effect of mineral fertilizers, bio-fertilizers and biochar application on production of garilic grown in sandy soil condition. Egypt J. Hort. 44 (2): 165- 181.

\section{الملخص العربي \\ تأثير استخدام محسنات التربة على خصوبة التربة وإنتاجية الذرة فى أرض حديثة الاستصلاح}

$$
\text { سهام محمود عبدالعظيم }
$$

الميسر ، بينما كان Mn للأراضى المعاملة بمحسنات التربة.

لوحظ أن تأثير البيوشار والكمبوست والسماد الحيوي مع

معدلات مختلفة من النيتروجين المعدني على كل من طول

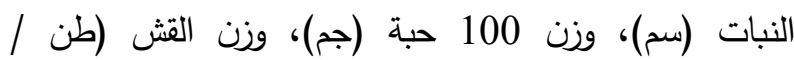
للفدان)، ووزن محصول الحبوب (طن / فدان) قد الى زيادتها مع زيادة معدلات النيتروجين المعدنى بإستثناء النباتات المعامله بالسماد الحيوي. كان تأثير إضافة محسنات التربة الى زيادة كبيرة في تركيزات N و P و K في القش والحبوب. وجد أن إضافة المحسنات التربة متحده مع معدلات مختلفة

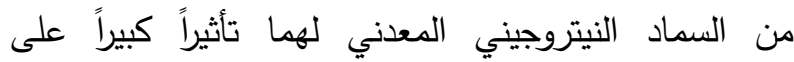
تركيزات Fe و Mn و Zn في القش وحبوب الذرة. مما سبق وجدنا ان إضافة محسنات التربة أدت إلى زيادة خصائص النمو ومحصول الحبوب من الذرة وتحسين الخواص الكيميائية للتربة والنبات.
أجريت تجربتان حقليتان في أرض رملية بمزرعة خاصة

فى القنطرة شرق بمحافظة الإسماعيلية خلال الموسمين الصيفين المتتالين 2018 و2019 لدراسة تأثير إضافة محسنات التربة (البيوشار والسماد العضوي والسماد الحيوي) مع أو بدون معدلات مختلفة من السماد النيتروجينى المعدنى على خصوبة التربة وإنتاجية الذرة. تم إجراء التجربة في في تصميم قطاعات منشقة مرة واحده بثلاثة مكررات. أشارت النتائج إلى أن درجة الحموضة في التربة و ملوحة التربة تميل إلى الانخفاض مع زيادة النيتروجين (EC (dSm"-1) المعدني متحد مع السماد العضوي والسماد الحيوي بالمقارنة بالبيوشار . كان متوسط اعلى القيم لمحتويات N و P و الميسرة في التربة هي 44.04 و 5.93 و 177.00 (ملليجرام /كيلوجرام للتربه) التي تمت معاملتها بواسطة معدلات السماد النيتروجين المعدني متحده مع الكمبوست مقارنة بالمعاملات الأخرى. كان تأثيرمحسنات التربة معنوى بالنسبة لل Fe و ل 